Turkish Online Journal of Qualitative Inquiry (TOJQI)

Volume 10, Issue 4, October 2019: 542-565

DOI: $10.17569 /$ tojqi.592046

Research Article

\title{
Developing EFL Learners' Speaking and Oral Presentation Skills through Pecha Kucha Presentation Technique
}

\author{
Osman Solmaz ${ }^{1}$
}

\begin{abstract}
The goal of this study is to examine the potential of Pecha Kucha presentation style for English language learners who are prospective teachers of English. The participants were students enrolled in an advanced-level speaking course in the English language teaching department of a state university in Turkey between 2016 and 2018. Students were required to make presentations in Pecha Kucha format, a fast-paced, time-constrained presentation technique. As part of the study, 102 students completed an open-ended survey and a total of 12 students representing cohorts from each year participated in semistructured focus group interviews. Thematic data analysis illustrated benefits of using the presentation style such as perceived development in speaking, self-confidence, time management and presentation skills, and drawbacks including an increase in anxiety, steep learning curve, and constraints due to the format. In addition, the findings showed that English language teacher candidates recognized the technique's potential and reported a high rate of intention to integrate it into their future language teaching pedagogies. The study is concluded with the discussion of implications for EFL learners, preservice language teachers, and educators in higher education context.
\end{abstract}

Keywords: English as a foreign language, Pecha Kucha, pre-service English language teachers, teaching speaking.

\footnotetext{
${ }^{1}$ Dr., Dicle University, Ziya Gökalp Faculty of Education, Department of Foreign Language Education, osolmaz@dicle.edu.tr, https://orcid.org/0000-0003-2983-1177.
} 


\title{
Yabancı Dil Olarak İngilizce Öğrenenlerin Konuşma ve Sözlü Sunum Becerilerini Pecha Kucha Yöntemiyle Geliştirme
}

\begin{abstract}
$\ddot{O} z$
$\mathrm{Bu}$ çalışmanın amacı, Pecha Kucha sunum tekniğinin İngilizce öğretmeni olacak İngilizce öğrencileri için potansiyelini araştırmaktır. Çalışmanın katılımcılarını 2016 ile 2018 yılları arasında Türkiyedeki bir devlet üniversitesinin İngilizce Öğretmenliği bölümünde ileri düzey bir konuşma dersi alan öğrenciler oluşturmuştur. Öğrencilerden hızlı tempolu ve zaman sınırlamalı bir sunum tekniği olan Pecha Kucha formatını kullanarak sunum yapmaları istenmiştir. Çalışma kapsamında 102 öğrenci açık uçlu bir anket doldurmuş, farklı yıllarda bu dersi alan öğrencileri temsilen oluşturulan toplam 12 öğrenci ise yarı yapılandırılmış odak grup görüşmesinde yer almıştır. Tematik veri analizi, bu sunum tekniğinin konuşma, özgüven, zaman yönetimi ve sunum becerileri alanlarında pozitif bir gelişime, kaygı düzeyinde artış, zorlu öğrenme süreci ve formatın sınırlılıkları gibi hususlarda ise negatif bir etkiye sahip olduğunu açığa çıkarmıştır. Bunun yanı sıra, bulgular İngilizce öğretmen adaylarının tekniğin potansiyelinin farkına vardıklarını ve tekniği gelecekteki dil öğretim pedagojilerine dâhil etme konusunda yüksek oranda bir niyete sahip olduklarını belirttiklerini göstermiştir. Çalışma, yükseköğretimdeki eğitmenler, yabancı dil öğretmen adayları ve yabanc1 dil öğrencileri için çıkarımların tartışmasıyla sonuçlandırılmıştır.
\end{abstract}

Anahtar Sözcükler: Yabancı dil olarak İngilizce, Pecha Kucha, İngilizce ögretmen adayları, konuşma ögretimi 


\section{Introduction}

Oral communication in the target language is among the primary goals of foreign language teaching. Educators in higher education context aim to provide opportunities for learners to reach a sufficient proficiency level in speaking despite being challenged by reasons such as large classes and dense syllabi (Angelini \& García-Carbonell, 2019). This is particularly true for English language teaching (ELT) departments, which require EFL teacher candidates to master speaking skills for various reasons, such as communication in general and for future instruction as learners are expected to be equipped with different speaking strategies to use when they become teachers (Widyaningrum, 2016). Courses offered in ELT departments typically require students to make oral presentations as extensive speaking activities, which can create meaningful opportunities for teacher candidates to develop their speaking and presentation skills, actively engage them in the content, and encourage collaborative learning. Given the development of information technologies creating new ways of making presentations, students should be encouraged to deliver their presentations by exploring different technologies which might lead to better oral communication skills compared to traditional presentation tools (Murugaiah, 2016).

Pecha Kucha, "chit chat" in Japanese, is one of the innovative and creative presentation styles (https://www.pechakucha.com/). The technique requires presenters to deliver content in 20 slides, each of which automatically runs for 20 seconds within a program like PowerPoint (PPT). The presentation is quite visual as it emphasizes the use of photos, images, or graphics, while text use is often limited, thus ensuring a quick and clear delivery of content. The technique has been previously adopted in university-level classes as an option to develop learner presentations, minimize the disadvantages of traditional PPT presentations, and create opportunities for self-reliance and autonomy. The results of previous research examining the use of Pecha Kucha (PK) in higher education settings suggest that learners have positive attitudes towards PK use (Mabuan, 2017), while some of them have preferred the technique over traditional PPT presentations (Beyer, Gaze, \& Lazicki, 2012). The investigation of PK use in EFL classes illustrated that the technique had positive contributions to learners in several ways including a perceived development in speaking (Colombi, 2017) and fluency (Zharkynbekova, Zhussupova, \& Suleimenova, 2017), opportunities for additional language 
practice (Hayashi \& Holland, 2016), improvement in presentation skills (Nguyen, 2015), and a reduction in public speaking anxiety (Coşkun, 2017). In addition to the identified advantages, PK was criticized due to its fast-paced rigorous nature of format, which sometimes created pressure on learners (Ruiz, 2016). Nevertheless, PK was found to have potential as a creative instructional technology to develop various learner skills in tertiary-level EFL classes. Despite the benefits put forward by previous research, the number of studies specifically examining English language teacher candidates employing the technique as EFL learners and studies conducted in Turkish higher education settings is limited. Guided by the literature in the field, the present study aims to illustrate the perspectives of tertiary-level EFL learners studying at the department of ELT in a Turkish state university. In addition, the study examines teacher candidates' intentions to adopt PK presentation in their future teaching in relation with their PK experiences at university.

\section{The Use of Pecha Kucha in Higher Education Context}

The ubiquity of Pecha Kucha (PK) presentation style has increased in higher education classes in recent years, leading researchers to explore the potential of the technique in different undergraduate settings, such as psychology (Beyer, 2011); marketing (Levin \& Peterson, 2013) and medicine (Abraham et al., 2018). A growing corpus of research investigating the use of PK presentation in second/foreign language learning and teaching contexts has emerged as well (e.g., Nguyen 2015, Ruiz, 2016). This section is organized in a way to highlight a review of the literature on the examination of PK technique in both general higher education context and specifically second language learning and teaching settings.

Among the earliest works investigating the effectiveness of PK presentation was the study conducted by Klentzin, Paladino, Johnson, and Devine (2010), which employed a post-test experimental design to compare PK with a traditional and longer PowerPoint-supported lecture. Following the participation in a plagiarism-related lecture by librarians either in a PK or a PowerPoint (PPT) format, students completed a test on the delivered content and achieved similarly higher performances. The findings suggested that PK can be employed to present information at a similar quality level yet in a shorter period of time compared to a traditionally longer PPT. Similarly, Beyer (2011) designed a series of studies in which undergraduate students enrolled in psychology courses were required to make a presentation in either PK or 
traditional PPT format. Based on instructor's evaluations, the results suggested that the overall quality of PK presentations was higher as compared to PPT presentations. In a similar study, Johnson and Christiansen (2011) compared traditional PPT presentation with a SimplifiedVisually Rich Approach, which was similar to PK. They reported that college students had significantly higher satisfaction although no difference was found with respect to learning outcomes. In another study, Beyer et al. (2012) compared student interest and information retention from peer PK and PPT presentations by sixty-seven undergraduate students. They found that presentations in PK format were more favored by students although there was no difference in recall of the material. In a similar vein, students enrolled in a marketing course developed an appreciation for the PK format through the semester despite a self-reported apprehension in the beginning (Levin \& Peterson, 2013). Finally, medical students in the study of Abraham et al. (2018) had positive perceptions towards the use of PK format citing benefits like organizing content, applying creativity, and presenting concise information.

In addition to the studies above, there are several examinations illustrating the integration of PK presentations into L2 teaching and learning contexts. Due to the origins of the technique, it is perhaps not surprising to see the majority of research being conducted in Asia, such as Singapore (Ruiz, 2016), Malaysia (Murugaiah, 2016), and Philippines (Mabuan, 2017). Among the common themes emerging across the studies were; a) students often displayed positive attitudes towards the implementation of PK as part of language classes (e.g., Colombi, 2017), b) learners reported a perceived increase in their speaking skills (e.g., Nguyen, 2015), and selfconfidence (Thomsett \& Shaw, 2014), c) PK had the potential to foster English as a Foreign Language (EFL) students' L2 oral presentation skills (e.g., Murugaiah, 2016), d) students reported negative experiences with respect to time limitation and lack of flexibility due to PK format (e.g., Ruiz, 2016). In addition, English as a Second Language students felt that they achieved learning outcomes through an innovative way (Thomsett \& Shaw, 2014), while Spanish learners reported a higher level of difficulty for preparing to present in PK format compared to traditional PPT (Ruiz, 2016). Among the other findings reported in the literature were students becoming more autonomous in organizing their ideas and active in learning English (Baskara, 2015), accessing more opportunities to practice language (Hayashi \& Holland, 2016; Mabuan, 2017) and learners applying creativity to overcome certain limitations of the technique (Colombi, 2017). 
Limited research to date has explored PK's affordances for the students at the department of English Language Teaching (ELT). In one of the studies, Widyaningrum (2016) examined the role of PK in the development of teacher candidates' explaining skill through a quasiexperimental study. The data collected through survey, observation, and comprehension test indicated that PK could positively improve ELT students' performance and comprehension along with explaining skill. It was also reported that PK can be more effective compared to a typical PPT presentation when students are well-prepared. Another study, which was conducted in the context of Turkish higher education, particularly examined the effect of PK on the public speaking anxiety of the EFL learners through a pre- and post-test experiment (Coşkun, 2017). According to the results of the study, English public speaking anxiety of the students were found to be significantly reduced, which suggested that the format could be adopted in EFL classes for specific purposes such as lowering speaking anxiety.

Given that the research featuring English language teacher candidates as participants or Turkey as the context is limited, the present study aims to address the following research questions: 1 . What are the benefits of Pecha Kucha presentation technique in tertiary-level EFL speaking classes?; 2) What are the drawbacks of Pecha Kucha presentation technique in tertiary-level EFL speaking classes?; 3) What are prospective English language teachers' intentions regarding the adoption of Pecha Kucha presentation technique in their future teaching pedagogies?

\section{Methodology}

\section{Participants}

The participants in the study consisted of 102 students from the English language teaching (ELT) department at a state university in Turkey. The students were pursuing a degree to become a teacher of English. The majority of participants were female, which reflected the overall gender distribution at the department (Table 1). The mean age of the participants was 24 in the range of 19 and 44. Participants' proficiency level of English varied between upperintermediate and advanced, while their self-reported speaking proficiency level differed compared to other skills. 75 participants (73.5\%) had never heard of Pecha Kucha (PK) 
technique prior to the speaking course they were enrolled in, while 27 students $(26.5 \%)$ had known about PK beforehand although none of them made presentation in this format.

Table 1

Participants' Demographics

\begin{tabular}{llcc}
\hline Variables & & Number & $\%$ \\
\hline Gender & Female & 73 & 71.6 \\
Age (years) & Male & 29 & 28.4 \\
& $19-21$ & 37 & 36.3 \\
& $22-24$ & 40 & 39.2 \\
Grade & 25 and above & 25 & 24.5 \\
& Sophomore & 31 & 30.4 \\
& Junior & 27 & 26.5 \\
Perceived level of speaking proficiency & Senior & 44 & 43.1 \\
compared to other areas & Lower & 25 & 24.5 \\
& & & \\
& Same & 47 & 46.1 \\
& Higher & 30 & 29.4 \\
\hline
\end{tabular}

\section{Pedagogical Instruction and Procedure}

Informed by the literature on the use of Pecha Kucha (PK) as a presentation tool in English language classes, the project was designed and implemented as part of a third semester advanced-level speaking course titled Speaking and Oral Expression Skills. The instructor, who was the researcher, had previous experience in teaching various skills including speaking in undergraduate English language teaching (ELT) program. The course was designed to create opportunities for students to develop and practice their oral communication skills. Prior to the course, all students had taken reading, writing, speaking, and listening courses for a year at university. Three different cohorts who took the course in the fall semesters of 2016, 2017, and 2018 participated in the study. The first cohort, senior students in the current study, had taken the course in 2016. The second cohort consisting of junior students was enrolled in the course in 2017, while the third cohort students took the course in 2018.

As part of the instruction, students were introduced to Pecha Kucha (PK) presentation technique, a time-constrained fast-paced model to deliver presentations during the first few weeks of the semester. They were provided with examples and explanations for guidance. In an effort to encourage learners to focus more on the content, a PowerPoint template adapted 
for PK presentations (i.e., 20 slides, automatic transitions between slides) was shared with students. For the first and second cohorts, all participants were required to choose a topic of their own choice and make a presentation in PK format. Participants' performances were evaluated through a rubric, which was created by the instructor. Mainly adopted from the oral assessment scales of Common European Framework of Reference for Languages (CEFR), the rubric consisted of five main categories, which emphasized the key areas for evaluation: Fluency and Accuracy, Content, Preparation \& Time Management, Post-Presentation, and Participation. All of the students knew that $50 \%$ of their final grades consisted of their PK performance and participation as also indicated in the course syllabus. For the third cohort, students were required to make two presentations in PK format. They were allowed to choose a topic of their interest for the first presentation, whereas they were required to choose a subject related to English language learning and teaching for the second presentation. A list of optional topics for the second presentation was provided. It was indicated in the course syllabus that first and second presentations had 50\% of their mid-term and final exam grades respectively.

Following the topic-related feedback provided by the instructor, all of the students in each cohort performed their presentation during mid-term and finals' weeks in their respective years. As clearly bounded by the format, each presentation took a total of 6 minutes and 40 seconds. In order to encourage students to listen to their partners and create opportunity for the presenter to engage in a post-presentation discussion, the audience was required to ask several questions pertaining to the presentation topic, while the presenter was expected to interact with his/her colleagues. Overall, the presentation including the follow-up section consisted of an approximately 10-minute performance.

\section{Data Collection and Analysis}

The sources of data in the study consisted of an open-ended survey and semi-structured focus group interviews. The main goal of administering the survey, formed by the researcher, was to collect demographic information of participants and their comments about multiple aspects of implementing PK presentation in tertiary-level speaking classes. In addition, it was aimed that a larger number of students could be reached. The survey consisted of questions seeking information such as learners' overall experiences with PK, differences in their opinions before and after presenting with PK technique, their future plans pertaining to the use of PK when 
they are teachers of English. The open-ended survey was distributed to sophomore, junior, and senior students who previously took the Speaking and Oral Expression Skills course through online learning management system. A total of 102 students completed and submitted the online survey. In an effort to document a richer and in-depth account of learner experiences and to complement survey data, semi-structured focus group interviews were carried out. Focus group interview was preferred over individual interviews for the purposes including; a) the possibility of access to a purposive sampling of a specific population, b) potential benefit gained through the dynamic nature of the social interaction occurring between group members (Vaughn, Schumm, \& Singagub, 1996), c) alternative interpretation of data collected from open-ended survey through reaching more detailed account of learner experiences. In the online survey, participants were invited to take part in an interview with the researcher. There were a total of 30 volunteers ( 8 sophomores, 12 juniors, and 10 seniors). Three focus groups consisting of 12 students representing their respective cohorts were formed based on volunteers' availability at the time of interviews. Focus Group 1 consisted of 4 sophomore students (1 female, 3 male), while there were 5 junior students (4 female, 1 male) in Focus Group 2 and 3 senior students ( 2 female, 1 male) in Focus Group 3. In order to maximize the group synergy and increase student speaking time, participants were placed in their cohorts. This was also required as the questions addressed in each focus group were slightly changed. For instance, an inquiry about the long-term effect of PK presentation on students were only addressed to junior and senior students as it has been more than a year since they presented in PK format. The interviews took place in a quite office space on campus and volunteers were encouraged to reflect on their experiences before, during, and after PK presentations. The recorded interviews were transcribed verbatim following the completion of each interview.

A fine-grained qualitative analysis of the data collected from the open-ended survey and interviews was carried out and both first and second cycle coding methods were applied (Saldaña, 2015). As part of first cycle method, major themes and discourse strands emerging from the data were identified through a descriptive exploratory coding process. This cycle was built upon the initial coding process which started during the collection of data for the purpose of documenting notes for future considerations as the study progressed. Simultaneous data analysis during data collection allows the researcher "to focus and shape the study as it proceeds" (Glesne, 2011, p. 188). For second cycle coding, the data set was reread for the purpose of eliciting codes illustrating ideas, key concepts, and values which are placed under 
major themes. In an effort to keep data grounded in participants' own language use, In Vivo coding, referring to the coding based on participants' actual language use, was employed in this cycle as well. The analysis entailed an iterative process, which recognized revisiting of the codes for the purpose of relabeling and refining them as needed. Responses and quotes exemplifying each code were compiled based on the final data analysis. This presented an opportunity to integrate student voices, which are integrated into the section below (e.g., R22 representing survey respondent 22). Following the finalization of each themes and subcategories, the qualitative data was quantified for two main themes (i.e., benefits and drawbacks) for an exploratory review of the data. It is important to underscore that the researcher was the only coder, which formed one of the limitations of the present study.

\section{Findings}

\section{Benefits of Pecha Kucha Presentation Style}

The first major theme emerging from survey and semi-structured focus group interviews was about the benefits of Pecha Kucha (PK) presentation technique for English language learners. According to the content analysis of the open-ended survey, several benefits, which are echoed during the interviews, were reported by learners: fluency in speaking, time management, overall speaking, presentation skills, self-confidence and pronunciation (Table 2).

Table 2

Benefits of Pecha Kucha Reported by EFL Learners

\begin{tabular}{lcl}
\hline Statements & Frequency & \multicolumn{1}{c}{ Sample learner responses } \\
\hline Fluency in Speaking & 42 & $\begin{array}{l}\text { "After my Pecha Kucha presentation, I started to think that I can be } \\
\text { more fluent when I speak." } \\
\text { "Students become aware of the importance time and they can use their } \\
\text { time effectively." } \\
\text { "It provides students to improve their speaking skills by giving certain } \\
\text { information about any topic within a limited time." }\end{array}$ \\
Presentation Skills & 29 & $\begin{array}{l}\text { "It improves our effective presentation skills such as getting rid of } \\
\text { useless details and focusing." } \\
\text { "This technique increases my level of self-confidence when I speak } \\
\text { English" }\end{array}$
\end{tabular}


"Because students are well-prepared, it improves fluency and pronunciation."

A perceived improvement in speaking fluency as a benefit of PK technique was explicitly stated by nearly half of the respondents in the study. Learners viewed the technique as an opportunity which "offers the students to speak without stopping too much to think or fill the sentences with pauses" (Interviewee 6). One student cited the time limitation as the reason of the need for fluency by stating "we give information about a topic in a short time therefore we use language fluently" (R63). Learners also expressed statements indicating a sense of selfassurance and self-awareness of gaining fluency during and after the presentations ("I realized that I have fluency in speaking during PK presentation”, R33). In addition to fluency, learners reported that they believed PK could contribute to their speaking in general and public speaking skills in particular. It is perhaps best evidenced in one of the learners' response: "It is a very good technique for speaking skills and helps students to get over their fears about being watched or being in front of the others" (R46). Some students opined that PK contributed them through teaching "how you can speak comfortably in front of audiences" (R53), and how to "manage stress while presenting or talking about something in front of the people" (R40).

Overall, learners agreed that PK contributed to the different aspects of their speaking skills, which were also reflected upon by a participant during the focal group interviews:

"I think the experience helped me with my speaking skills. It was particularly helpful in terms of achieving fluency in speaking. The technique forced us to speak without fillers in our sentences during the presentation and it is one of the major advantages of the technique." (Interviewee 7, Focus Group 2)

Development in time management skills was frequently raised by the participants (e.g., "The most beneficial part of $P K$ for me was that it supported me to improve my time management skills", Interviewee 11), highlighting the requirement of presenting in a limited time as exemplified in "You indicate a certain time and you try to finish your planned presentation in this specific time. It provides you to be punctual" (R97). Also specified was relationship between the need for practice and time limitation, which might play a role in improvement in time management skills. 
A recurring theme across student responses was about how PK contributed to the development of their presentation skills. Drawing attention to the specific format of PK, participants positively approached the fact that "there is not much writing part that controls your speaking" (R44), which helped them to focus on speaking, visuals on the screen and time management. Other benefits related to presentation strategies reported included getting rid of useless details, increased concentration, focusing on the attention of the audience, stress management, and using images to communicate ideas. One student mentioned some of those strategies during the interview:

"We were expected to make presentation in other courses as well. Following the Pecha Kucha experience, I realized that I had learnt to overcome challenges of making good presentations such as keeping eye contact with the audience and time management. I think PK helped me with taking control of my voice, which is soft. I believe I learnt to use it more efficiently because I had to explain my topic in a short time in the most effective way possible." (Interviewee 12, Focus Group 3)

Another major subtheme was concerned with PK's potential to increase learners' selfconfidence. Some students emphasized a positive change in their level of confidence and pointed out that PK "gives confidence to students and encourages learner autonomy" (R77), while others remarked on how completing their presentation made them feel about themselves: "It gives the feeling and excitement of achieving a great job in a short time" (R91), "It made me feel really good because I had doubts about being able to pull it off, but I did it" (Interviewee $8)$.

In addition to the aforementioned benefits, among the positive aspects of PK were potential improvement in areas including but not limited to pronunciation, vocabulary, reading, and cultural knowledge. Before and during the presentation, students were required to employ different skills for a successful outcome. To illustrate, they were expected to bring together a set of information and convey their ideas clearly, which maximized the importance of pronunciation, reading, and vocabulary, thus leading to an added concentration on these areas as reported by students: "During preparation and presentation, I learnt a lot of new vocabulary from a broad range of fields and the way these words were pronounced" (Interviewee 12), and "Preparation for PK is beneficial since it requires a lot of reading and giving opinions in a systematic order" (R62). 


\section{Drawbacks of Pecha Kucha Presentation Style}

A recurring major theme among participants was challenges the learners faced and drawbacks of PK as a presentation technique. Among the challenges posed and critiques made were time constraint, anxiety, steep learning curve, neglecting accuracy in speaking, and memorization (Table 3).

Table 3

Drawbacks of Pecha Kucha reported by EFL learners

\begin{tabular}{lcl}
\hline Statements & Frequency & \multicolumn{1}{c}{ Sample learner responses } \\
\hline Time Constraint & 38 & $\begin{array}{l}\text { "I think the time limitation is the major handicap because it can cause } \\
\text { students to rush and errors may occur as a result of that." } \\
\text { "Anxiety is necessary for learning process but it makes students have high } \\
\text { anxiety because of the fast flow of time." } \\
\text { " It is more difficult than traditional presentation because there are no } \\
\text { sentences to read, but only images that relate to your topic that you should } \\
\text { speak about." }\end{array}$ \\
$\begin{array}{l}\text { Steep Learning Curve } \\
\text { "Students do not care about their mistakes because they speak fast." } \\
\text { Memorization }\end{array}$ & 11 & 6
\end{tabular}

Compared with the other negative aspects, time constraint was criticized the most. Some students felt frustrated while trying to ensure that their presentations fit into PK technique's format in a specific time frame. They argued that "sometimes time may not be enough to convey the knowledge" (R75) or "students cannot speak exactly what they want to say in a limited time" (R69), and when they present, they "pay too much attention to time and it prevents speaking more fluently" (R79). Constantly focusing on time might have limited learners' flexibility of delivering presentation and conveying the planned content in an accurate way. A response given by one student revealed how time limitation might lead to anxiety throughout the process:

"You may be interrupted due to short time, and may not be clear enough to convey your messages to listeners. This short time may force people to be fast. If not speaking on time, there will be chaos in your mind and you feel anxious, uneasy and upset." (Respondent 50, open-ended survey)

As illustrated above, many students believed that time limit and the anxiety level of learners had positive correlation. Responses received through the open-ended survey featured examples revealing the relationship such as "Time is limited, so you feel nervous and you may make mistakes while you are speaking" (R2), "Time may not be enough and it creates tension on 
people" (R100), "You have to keep an eye on time and try to remember what you plan to say at the same time which is difficult to balance" (Interviewee 9). Increasing level of anxiety, however, was also associated with other factors such as lexical knowledge and the audience. For instance, one student mentioned how time limit may inhibit the need to employ a wide variety of vocabulary during presentation: "You need to use so many different vocabularies and it may be hard when you are under pressure as you may lose self-confidence" (R7). Another student emphasized the role an audience can play in anxiety students might feel: "It can create fear but it depends on for whom or the number of the people you would present" (R23). Anxiety was reiterated as a challenge during semi-structured focal group interviews, in which one student reflected on the issue:

"It is true that time limitation creates some tension on students because the presenter tends to think that everything will be lost if something is forgotten during the presentation. The time flows as he tries to remember a word, for example. And then, he moves on the next slide: "How I am going to make connection between them? "If he is not used to it or is not well-prepared and cannot remember a word or make the right connection, he falls head over heels. The stress begins from the moment of thinking about that possibility." (Interviewee 10, Focus Group 3)

The majority of students did not have previous experience with Pecha Kucha as a presentation technique, the specific format of which was criticized by some learners often due to a lack of familiarity with the technique. Despite a short presentation time, the need for a long period of time for preparation and rehearsal was present among student responses. Some students thought that preparing to present in PK format was harder and took more time than other technologyenhanced presentations. It was sometimes due to the specific guidelines given for the presentation topic ("It may be difficult to choose a suitable topic because the subject should not be too wide or narrow", R91), the stress experienced by learners while trying to reach a target content ("Finding useful information takes more time", R60), or practicing the content of the presentation ( "We were in search of trying to express the information in the shortest yet meaningful way possible in 20 seconds", Interviewee 7). Learners also noted that the format might cause presenters to neglect accuracy during presentations: "Because of time limit, accuracy is ignored while speaking” (R14). Furthermore, they mentioned that they did not have enough time to correct themselves. As a result, both meaning in a particular part of presentation or overall quality of content delivery were negatively affected: "Sometimes finding the exact word can be difficult and while time is passing by, you have to find a way, if 
not, the chain of meaning is deteriorating" (R4). Finally, several students opined that struggling presenters might gravitate towards memorization as a solution for challenges they may experience ("The stress I had made me memorize some of my sentences so that I could overcome my anxiety”, Interviewee 3$)$.

\section{English Teacher Candidates' Future Intentions to Adopt Pecha Kucha}

Given that participants of the study were English language teacher candidates, the study investigated their future intentions to integrate Pecha Kucha (PK) as a presentation technique in their teaching as well. Data analysis indicated that sixty-seven students reported positive intentions to adopt PK when they become teachers of English. Of the remaining participants, thirteen students reported that they did not plan to use the technique, while eight pre-service teachers were unsure and fourteen teacher candidates did not provide any comment on the subject.

Many teacher candidates explicitly stated their intentions to adopt the technique through some changes in the format (e.g., time and number of slides), frequency of making presentation, and the type of assignment for presenting in PK format $(N=22)$. Majority of the participants planned that they would extend the time for presentations ("I will give more time for [my students'] presentation as 20 seconds are not enough for each slide", R1; "I will prepare the time according to students' level", Interviewee 12; "For primary school students, I can keep everything same but have no time constraints for them", Interviewee 3) and limit the number of slides ("I can use it for high school students by giving them more time with less slides and let them talk more", R4). There were students who noted that they would follow the format without any change and one participant summarized her future plans by stating:

"I think I will use this technique when I become a teacher. I can adapt the technique according to my students' proficiency levels but I would not change the format. I would let my high school students have the control over their presentations and choose the topics by themselves. They will look at the images and speak as suggested by the format. I will make sure that they feel comfortable while presenting." (Interviewee 11, Focus Group 3)

Participants' future intentions featured the adoption of PK technique with a change in the frequency of using it. Various opinions were voiced and these included the weekly ("I would 
like to use it to improve my students' speaking and presentation skills by giving weekly assignments to some of them", R25) and monthly use of PK in their classes ("I want to use it once a month for the improvement of speaking and listening skills”, R8). Some teacher candidates reported that they would use the technique in their presentations while teaching: "Every month, I will choose a topic which might interest students and I will present it by using this technique” (R97). The nature of PK use as an assignment also differed among participants. To illustrate, some students planned that they would give it as a term paper or a performance project, while others intended to use it instead of a written exam. Another student expressed that she would organize a PK competition for her students. Considering the challenging nature of PK's fast-paced and time-constrained format led some teacher candidates to envision that presentations could be delivered as a pair or group work ("Maybe, instead of an individual work, it can be a group activity and members can present in turn", R60).

Given that participants are expected to teach English at primary, secondary, or high schools when they graduate, it was not surprising to observe that several teacher candidates $(N=16)$ possessed a positive perspective towards with an emphasized awareness regarding the technique's appropriateness for their future students' level of English. They opined that they would use the technique depending on their future students' linguistic repertoires ( If my class is suitable for this technique, I can use it according to their levels", R70), whether they study at high school or not ("I can use this at high school, not for young learners", R67; "I think it can be difficult for children but if I work at high school, I can use this technique by adjusting time according students' levels and their topics", R35), their ages ( "I can ask my adult students to make a PK presentation and talk about their lives, presenting their childhood photos, memories etc.", R61; "I think it will be more effective for adults”, R102), their level of English ("Yes, definitely [I will use], especially when my students are at an advanced level", R22; "I can use it for intermediate students", R3). One of the interviewees stressed the importance of learning to present in this technique as soon as possible:

"I think that it would be better if students become familiar with such techniques starting early ages. We did not know about PK until last year, when we were sophomores. I think that we could have learnt about it earlier. Having a previous experience before university can present learners to have alternatives when they are expected to make presentations." (Interviewee 5, Focus Group 2) 
The analysis of the data showed that several students indicated the underlying reasons for their intentions to adopt PK $(N=16)$. Among the cited motivations were developing future learners' speaking, listening, presentation, and time management skills, which showed that they recognized the potential of the technique. Many students acknowledged potential benefits of PK for their students' speaking and listening skills: "I can use this technique to help my students to speak comfortably" (R18), "There's no doubt that I will use it especially for listening and speaking skills" (R33). Some teacher candidates concentrated more on PK's potential contributions to their students' presentation and time management abilities: "I'll use it when I want my students to make an impressive presentation" (R89), "I will use it as a speaking activity and to make my students learn how to manage time" (R29). Among the other reasons shared was developing students' critical thinking, helping them gain self-confidence, and knowing them better ("I can get to know my students with this activity as I can ask them to make a presentation about their daily life”, R41).

Finally, several students expressed that their future plans did not include the implementation of PK technique or they were not sure about it. They generally agreed that the technique required a high English proficiency, thus making it less suitable for their future learners. Two teacher candidates' reasons of not using the technique were concerned with the level of English they wanted to teach: "I am thinking of being a teacher in secondary school and this technique is not suitable for secondary school students' cognitive levels” (R72), “Actually, I am not going to use this technique in my classes because I will be a teacher for the elementary school students and it will be hard for them." (R93). Some of the participants were unsure about implementing PK and noted that it depended on the level and needs of their future learners.

\section{Discussion}

The present study aimed to investigate EFL learners' perspectives towards the use of Pecha Kucha (PK) presentation technique in tertiary-level speaking classes in Turkish higher education context. The data collected from 102 respondents by means of an open-ended survey and 3 semi-structured focus group interviews suggested that learners viewed PK technique positively and some of them indicated a preference over traditional presentation techniques. This finding ties well with previous research wherein learners displayed positive attitudes 
towards PK (Mabuan 2017; Ruiz, 2016) and some students preferred the style versus typical PowerPoint (PPT) presentations (Beyer et al., 2012). Regarding PK's linguistic contributions, the findings of the present study demonstrated that learners had a perceived development in overall speaking, fluency, and pronunciation. A similar conclusion was reached by several studies which highlighted student experiences illustrating PK's contributions to their overall speaking skill (e.g., Angelina, 2019; Colombi, 2017) and fluency (Zharkynbekova et al., 2017). Despite some students noting the fast-paced nature of PK leading to accuracy problems in speech, which was reported in the literature (Baskara, 2015), many learners agreed that PK provided them opportunities to engage in additional language practice such as reading and listening. This is consistent with what was observed in the previous research (e.g., Hayashi \& Holland, 2016), in which PK presentations provided a context for students to practice English.

A frequently reported drawback of PK use was associated with the rigorous nature of PK format featuring a constrained time and lack of flexibility. A similar pattern of results was obtained in several studies (e.g., Murugaiah, 2016; Nguyen 2015), which showed that such limitations could be frustrating for learners who have higher speaking anxiety or prefer a slower-paced presentation style. However, the results of the present study also suggested that the strict format of PK enabled learners to improve their time management skills as the technique forced them to use their time efficiently. Listing self-organization among PK's potential contributions to learners, Hayashi and Holland (2016) argued that PK encouraged learners to engage in careful planning and become more conscious about time before and during the presentation as "the time spent on the project's separate elements needs to be carefully managed"' (p. 308).

The role of PK in developing students' oral presentation skills was positively acknowledged by the participants. It was also evident from the findings that PK was challenging for some students as it requires learners to spend extra time and effort for preparation, the lack of which might lead to memorization of the presented material. The findings with respect to presentation skills are in accordance with those reported by several studies (e.g., Abraham et al., 2018; Colombi, 2017), in which PK was regarded as an effective way to improve students' presentation skills. Findings pertaining to the time and effort spent for preparation are also consistent with previous research (e.g., Angelina, 2019; Widyaningrum, 2016) with the exception of the study conducted by Beyer (2011) in a context featuring native English speakers. Considering the strict format of PK technique, it is perhaps not surprising as students 
need to devote time for content, visual design, and rehearsals, through which they need to achieve brevity for the purpose of delivering content in a timely manner. As also documented in the literature (Murugaiah, 2016), the task of presenting without text on slides in a limited time might cause some learners to memorize the information they present. Nonetheless, it was shown that such a process of preparation ensures the possibility of learners being more involved in the content, thus increasing awareness for self-organization, learning more about the topic, and engaging them in creative thinking (Thomsett \& Shaw, 2014).

A further finding concerns the anxiety level of learners, which was reported to have increased due to the PK format. Despite the fact that learners criticized the stress PK caused before and during the presentation, many of them indicated a perceived development in their selfconfidence following the PK experience. These results find support from the literature, in which students reported an increase in their level of self-confidence and nervousness being overtaken by the experience (Thomsett \& Shaw, 2014), contribution to their confidence to speak English in public (Lucas \& Rawlins, 2015), a perceived development in their autonomy (Baskara, 2015), and a significant reduction in their English public speaking anxiety (Coşkun, 2017). Considering students are expected to be well-prepared for their presentations, it is noted that the anxiety they experience before and during the presentation "is regarded as a good motivator that can keep the presenter alert and prevent the speaker from relaxing entirely" (Coşkun, 2017, p. 19). Thus, it may be argued that a potential drawback of the PK technique (i.e., rigorous format) may become its strength when learners manage to be in control of the pressure they might feel.

Finally, the findings suggested that EFL learners, who are going to become teachers of English when they graduate, recognized the potential of the technique for its possible contributions for students and reported a high rate of intention to integrate the technique into their future teaching pedagogies. These results unearth the previously underexplored area of pre-service language teachers' perspectives towards the use of PK as a presentation technique in their classes when they become teachers of English themselves. It is emphasized through the findings that teacher candidates' experiences and their increased awareness as a result of teaching techniques they observe might create new avenues for pre-service teachers to shape their future ideas of teaching. Therefore, it is argued that the employment of presentation techniques such as PK in 
teacher education programs might have the potential to contribute professional development of teacher candidates.

\section{Conclusion and Implications}

The present study adds to a growing body of research illustrating the potential of Pecha Kucha (PK) presentation style for English language learners from a variety of aspects including improvement in their speaking and other linguistic skills, development of oral presentation and time management skills, and a perceived increase in self-confidence, all of which may be considered as a further validation of the previous studies (e.g., Angelina, 2019; Mabuan, 2017; Ruiz, 2016) from a longitudinal perspective of learners. In addition, the findings of the study arrive at the conclusion that advanced EFL learners, who are studying at the department of English language teaching (ELT) to become teachers of English, display positive preferences with respect to the integration of PK into their future language teaching pedagogies, which might be considered a promising contribution of the present study to the underexplored strand in the literature.

While the current study investigates EFL learners' use of PK in a previously undocumented setting through highlighting the voices of many learners, it is imperative to note that the study is limited to a Turkish state university context and relied on students' self-perceptions. Furthermore, the design of the study fails to encompass students' presentation performances and their achievement of learning outcomes for a more comprehensive examination of the issue. However, the nature of the study, which allowed the inclusion of a high number of students' experiences in PK, and the data being enriched by semi-structured focus group interviews, might increase the generalizability of the research findings by overcoming the limitations imposed. It is suggested that future research examines the comparison of PK style and traditionally longer PowerPoint presentations with respect to learning outcomes and learner performances in second language classes. Due to the potential of PK for language teacher candidates, it is also recommended that researchers investigate PK's roles in the acquisition of content and skills required to become a teacher of English. Finally, it is vital to observe to what extent teacher candidates as EFL learners adopt the technique when they start their teaching career. 
The findings of the study have several implications for EFL learners, pre-service English teachers, and educators working in higher education settings. It is recommended that PK can be an efficient instructional technique which should be considered for implementation in tertiary-level EFL classrooms either as a requirement or an option for learner presentations. It could be particularly employed for developing learners' speaking and listening as well as their presentation skills. Considering the format-related challenges faced by students, it is suggested that appropriate modifications in time or the number of slides (i.e., 20 slides for 30 seconds each or 10 slides for 20 seconds each) might be provided for the first presentation of learners if they are expected to present more than once in a single semester. As suggested by Levin and Peterson (2013), learners might present in groups in an effort to familiarize students with the technique. It is crucial for teacher to provide students support by bringing sample PK presentations to the class, assisting learners with the organization of the content they are going to present, providing support particularly to the students who might experience a higher level of public speaking anxiety, and familiarizing themselves with PK presentation style. Finally, considering the potential of PK for language teacher education, the technique could be integrated into pre-service EFL teacher education programs as an alternative to traditional presentation techniques which are used for delivering content (Coşkun, 2017; Widyaningrum, 2016). 


\section{References}

Abraham, R.R., Torke, S., Gonsalves, J., Narayanan, S.N., Kamath, M.G., Prakash, J., \& Rai, K.S. (2018). Modified directed self-learning sessions in physiology with prereading assignments and Pecha Kucha talks: perceptions of students. Advances in physiology education, 42(1), 26-31.

Angelina, P. (2019). Improving Indonesian EFL students' speaking skill through Pecha Kucha. LLT Journal: A Journal on Language and Language Teaching, 22(1), 86-97.

Angelini, M.L., \& García-Carbonell, A. (2019). Developing English Speaking Skills through Simulation-Based Instruction. Teaching English with Technology, 19(2), 3-20.

Baskara, R. (2015). Developing students' autonomy in oral presentations through Pecha Kucha. Paper presented at the Teaching English as a Foreign Language Conference, University of Muhammadiyah Purwokerto, Indonesia.

Beyer, A.M. (2011). Improving student presentations: Pecha Kucha and just plain PowerPoint. Teaching of Psychology, 38(2), 122-126.

Beyer, A.A., Gaze, C., \& Lazicki, J. (2012). Comparing students' evaluations and recall for student Pecha Kucha and PowerPoint presentations. Journal of Teaching and Learning with Technology, 26-42.

Colombi, A.G. (2017). The Impact of Pecha Kucha Presentations in the Assessment of a Translation Studies Unit at the University of Western Australia. IAFOR Journal of Education, 5(3), 67-85.

Coşkun, A. (2017). The Effect of Pecha Kucha Presentations on Students' English Public Speaking Anxiety. Profile Issues in Teachers' Professional Development, 19, 11-22.

Glesne, C. (2011). Becoming Qualitative Researchers: An Introduction (4th ed.). Boston, MA: Pearson Education.

Hayashi, P.M., \& Holland, S.J. (2016). Pecha Kucha: Transforming Student Presentations. Paper presented at JALT 2016: Transformation in language education, Nagoya, Japan. 
Johnson, D.A., \& Christensen, J. (2011). A comparison of simplified-visually rich and traditional presentation styles. Teaching of Psychology,38(4), 293-297. doi: $10.1177 / 0098628311421333$

Klentzin, J.C., Paladino, E. B., Johnston, B., \& Devine, C. (2010). Pecha Kucha: using "lightning talk" in university instruction. Reference Services Review, 38(1), 158-167.

Levin, M.A., \& Peterson, L.T. (2013). Use of Pecha Kucha in Marketing Students' Presentations. Marketing Education Review, 23(1), 59-64.

Lucas, K., \& Rawlins, J.D. (2015). PechaKucha presentations: Teaching storytelling, visual design, and conciseness. Communication Teacher, 29(2), 102-107.

Mabuan, R.A. (2017). Developing ESL/EFL Learners' Public Speaking Skills through Pecha Kucha Presentations. English Review, 6(1), 1-10.

Murugaiah, P. (2016). Pecha Kucha style PowerPoint presentation: An innovative call approach to developing presentation skills of tertiary students. Teaching English with Technology, 16(1), 88-104.

Nguyen, H. (2015). Student perceptions of the use of PechaKucha presentations for EFL reading classes. Language Education in Asia, 6(2), 135-149.

Ruiz, C.G. (2016). Student perceptions of the use of Pecha Kucha presentations in Spanish as a foreign language. In Proceedings of EDULEARN16 Conference (pp. 7504-7512). Barcelona, Spain.

Saldaña, J. (2015). The coding manual for qualitative researchers (3rd ed.). London: SAGE.

Tomsett, P. M., \& Shaw, M. R. (2014). Creative classroom experience using Pecha Kucha to encourage ESL use in undergraduate business courses: A pilot study. International Multilingual Journal of Contemporary Research, 2(2), 89-108.

Vaughn, S., Schumm, J., \& Singagub, J. (1996). Focus group interviews in education and psychology. Thousand Oaks, CA: Sage Publications

Widyaningrum, L. (2016). Pecha Kucha: A way to develop presentation. Vision, 5(1), 57-74.

Zharkynbekova, S., Zhussupova, R., \& Suleimenova, S. (2017). Exploring PechaKucha in EFL learners' public speaking performances. In Proceedings of the 3rd International 
Developing EFL Learners' Speaking and Oral Presentation Skills through Pecha Kucha Presentation Technique

Conference on Higher Education Advances (pp. 189-198). Editorial Universitat Politècnica de València. 